\title{
Comparison of Flora of Small-Scale Mined and Unmined-Sites in Dunkwa-East Municipality, Ghana
}

\author{
Paul K. Essandoh ${ }^{1}$, Edward A. Ampofo ${ }^{2}$, Daniel Okae-Anti ${ }^{2}$, \& Isaac M. Bryant ${ }^{1}$ \\ ${ }^{1}$ Department of Environmental Science, School of Biological Sciences, College of Agriculture and Natural \\ Sciences, University of Cape Coast, Cape Coast, Ghana \\ ${ }^{2}$ Department of Soil Science, School of Agriculture, College of Agriculture and Natural Sciences, University of \\ Cape Coast, Cape Coast, Ghana \\ Correspondence: Paul K. Essandoh, Department of Environmental Science, School of Biological Sciences, \\ College of Agriculture and Natural Sciences, University of Cape Coast, Cape Coast, Ghana. Tel: \\ +23-32-4415-8690. E-mail: pessandoh@ucc.edu.gh
}

Received: July 26, 2019

Accepted: August 14, 2019

Online Published: September 30, 2019

doi:10.5539/enrr.v9n3p86

URL: https://doi.org/10.5539/enrr.v9n3p86

\begin{abstract}
The impacts of small-scale mining on the vegetal cover as well the livelihoods of communities in mined areas in developing countries such as Ghana are far-reaching. This study assessed the impacts of small-scale mining on flora of conservation and economic significance through quantification of species richness, and species diversity. Mined and unmined sites were chosen in the Dunkwa East Municipality of Ghana. Five belt transects each (200m $\times 200 \mathrm{~m})$ were constructed in both sites. Each belt transect was divided into 100 quadrats $(20 \mathrm{~m} \times 20 \mathrm{~m})$ and plant species in each of the quadrat were identified in the field and or the herbarium of the School of Biological Sciences, University of Cape Coast. One hundred and fifty seven species distributed in 140 genera and 54 families were identified in the mined area whilst the 209 species identified in the unmined area were in 185 genera and 73 families. Plant families Euphorbiaceae, Rubiaceae and Asteraceae were more diverse whilst Asteraceae, Poaceae and Euphorbiaceae were dominant in the unmined area. In the mined area, however, Poaceae, Euphorbiaceae and Asteraceae were more diverse. Pteridium aquilinum, Tridax procumbens and Waltheria indica in the unmined area and Chromolaena odorata, Sporobolus pyramidalis and Euphorbia hirta in the mined area were the dominant species. Small-scale miming activities have caused reduction in species diversity, richness and economic and commercial values in the area. Higher disturbance of the flora has resulted in more secondary species in the mined area. Restoration is required in the study area.
\end{abstract}

Keywords: Conservation, Diversity, Ecological, Guild, Mining, Richness, Small-Scale, Species

\section{Introduction}

Historically, Ghana has large deposits of mineral resources (Hilson, 2002), ninth on the list of countries that produce gold worldwide and the second largest producer of gold in sub-Saharan Africa (Arthur, Agyemang-Duah, Gyasi, Yeboah, \& Otieku, 2016) accounting for over 3\% of world gold production. Gold has provided enormous support to Ghana's economy in terms of capital formation, fiscal payment and employment (Lawson \& Bentil, 2014; Kuranchie-Mensah \& Amponsah, 2016; McQuilken \& Gavin, 2016). Small-scale mining apart from employing more people especially in the rural poor communities (Arthur et al., 2015) contributed between 20\% $35 \%$ of the estimated one million five hundred thousand ounces of gold produced in Ghana in 2014 (MinCom, 2015). According to Benkenstein (2012), the contribution of small-scale mining to gold production in Ghana increased sharply from $9 \%$ in 2000 to $23 \%$ in 2010 . Notwithstanding the support of small-scale gold mining to Ghana's growth and development, mining activities have impacted negatively on the environment rendering soils and water in most mined sites not suitable for many purposes (Kpan, Opoku, \& Anukwah, 2014).

The relatively regulated rehabilitation of large scale mined sites has not been replicated in small-scale mined sites in Ghana leading to degraded small-scale mined sites after mining has ceased. The degradation of the site is characterized by unfilled pits, poor landscaping, and depleted and fragmented plant cover (Edwards, 2014) rendering the sites not suitable for members of the community who are mostly farmers to re-use the land. From a spatio-temporal perspective, it is unclear what systematic changes in flora have occurred owing to mining 
activities. Thus, there is the need to know the functional relationship between small-scale mining activities and floral resources so as to help reduce the impacts of small-scale mining on the environment.

This study assesses the impacts of small-scale mining on the flora/vegetation through quantification of the species richness and diversity and also determines the economic and ecological significance, star-rating and genetic heat index (GHI) of the plant species. This will help to reveal how the species respond to significant influences on the floral community and the conservation values of the species.

\section{Methods}

\subsection{Study Area}

This study was carried out in the Dunkwa East Municipality, one of the oldest mining areas in the southern part of Ghana. The area lies within latitudes $5^{0} 30^{1}$ and $6^{0} 02^{1}$ North of the equator and longitudes $1^{0} \mathrm{~W}$ and $2^{0} \mathrm{~W}$ of the Greenwich Meridian (Figure 1). The study area falls within the semi-equatorial zone (Hall \& Swaine, 1981) and is characterized by a three-tree strata. The total annual mean rainfall is between $1200 \mathrm{~mm}$ and $2000 \mathrm{~mm}$ and the mean temperature ranges from $29^{\circ} \mathrm{C}$ in the hottest months and about $24^{\circ} \mathrm{C}$ in the coolest months (Dunkwa East Municipal Assembly, 2014). The rocks in the Municipality are mostly of the Birimian and Tarkwaian formation accounting for the rich mineral deposits. The geology of the area makes it attractive for mining and over the years, several concessions have been granted to companies and individuals for both large-scale and small-scale mining. This has resulted in the setting up of one of the District Mining Commission offices in Dunkwa-on-Offin. The study site offers unique opportunity to understand how the activities of small-scale mining affect land availability for agricultural activities especially farming in the local communities.

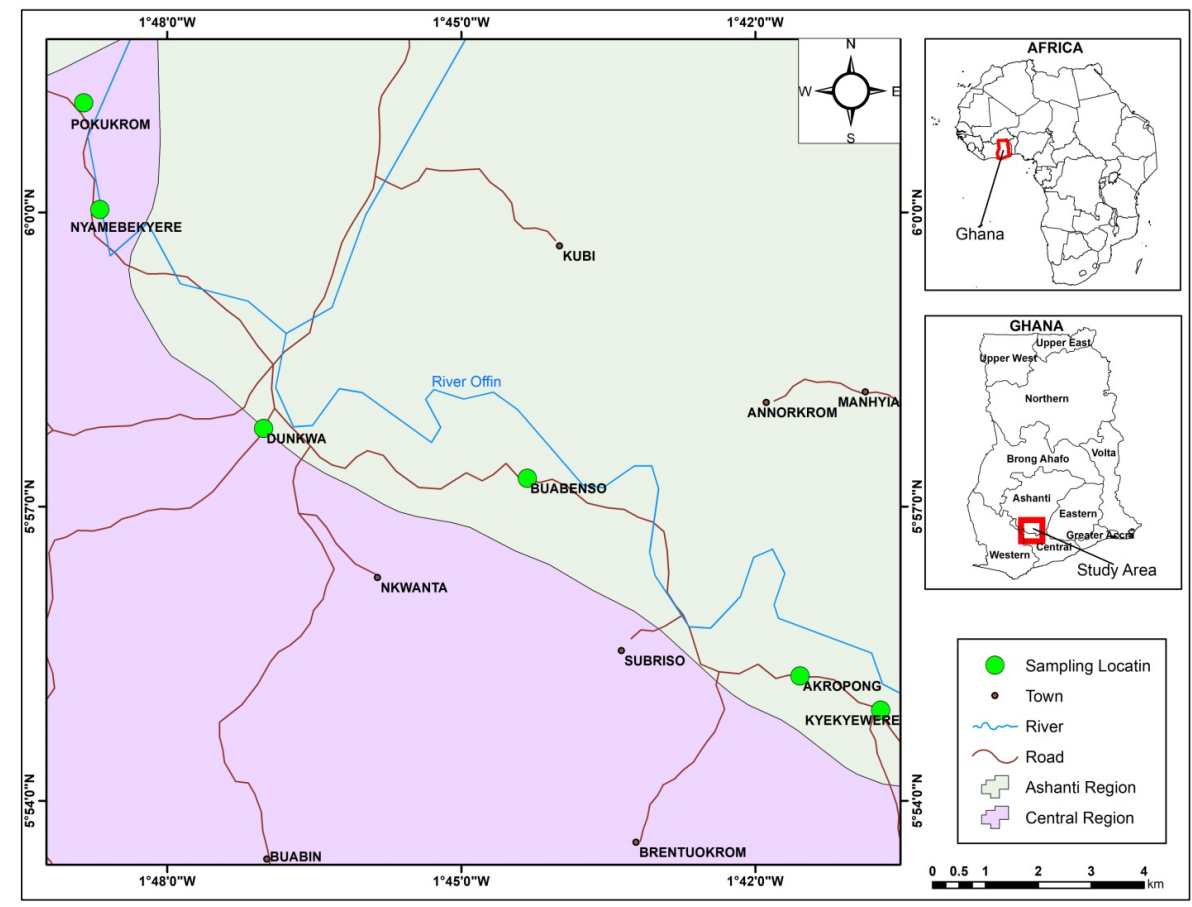

Figure 1. Map of study area showing the sampling sites

\subsection{Inventory of Plant Species}

Ten belt transects each measuring $200 \mathrm{~m} \times 200 \mathrm{~m}$ were constructed for the vegetation studies. Five of the belt transects $(200 \mathrm{~m} \times 200 \mathrm{~m})$ were constructed in the mined areas and another five belt transects $(200 \mathrm{~m} \times 200 \mathrm{~m})$ in the unmined areas. Each belt transect $(200 \mathrm{~m} \times 200 \mathrm{~m})$ was divided into 100 quadrats $(20 \mathrm{~m} \times 20 \mathrm{~m})$ and plant species in each of the quadrats $(20 \mathrm{~m} \times 20 \mathrm{~m})$ were identified in the field and or the herbarium of the School of Biological Sciences, University of Cape Coast. The plant species in the field were identified by the leaves, crown, bole, buttresses, slash exudates, texture, colour, smell, etc. For plant species that were not readily identified in the field, voucher specimens (leaves, seeds, fruits, bark slashes etc.) and photographs of the specimens were sent to the herbarium at the School of Biological Sciences, University of Cape Coast for identification. The herbarium identification was done by comparing with already identified herbarium material and the use of published flora. 
Herbarium staff at the School of Biological Sciences, University of Cape Coast also helped with the identification processes.

\subsection{Categorization of the Plant Species}

A comprehensive list of plants species obtained was used in the determination of the proportion of taxa, life-form, star rating and ecological guild of species in the study area. Star rating and ecological guild of species were determined with the help of the Forest of Ghana Graphical Information Exhibitor (FROGGIE) by Hawthorne (1993).

\subsection{Life Form of Plant Species}

The plant species in the study area were grouped into life forms on the basis of their similarities in structure and function. In this study, the plant species were grouped as Trees, Shrubs, Herbs, Lianes, Ferns and Climbers.

\subsection{Ecological Parameters of Plant Species}

Each of the belt transect $(200 \mathrm{~m} \times 200 \mathrm{~m})$ was sampled to determine ecological parameters of species in the mined and unmined study areas. In the determination of the density and frequency of plant species, only plants rooted in the quadrats $(20 \mathrm{~m} \times 20 \mathrm{~m})$ were counted. Shoots arising from a common tussock and those with rooted stolons were considered as single/individual plants.

\subsection{Density of Plant Species}

Plant species in each quadrat $(20 \mathrm{~m} \times 20 \mathrm{~m})$ were counted and the total number for each species recorded. This was done for 500 quadrats in the mined site and another 500 quadrats in the unmined site.

Density of plant species in each study site was then calculated as:

$$
\text { Density }=\frac{\text { Number of individuals of a particular plant species }}{\text { Total area of belt transect }\left(1000 \mathrm{~m}^{2}\right)}
$$

\subsection{Frequency of Plant Species}

100 quadrats $(20 \mathrm{~m} \times 20 \mathrm{~m})$ were constructed in each transect belt $(200 \mathrm{~m} \times 200 \mathrm{~m})$. The presence or absence of a particular plant species in each quadrat was recorded for the determination of frequency.

The frequency of each plant species was obtained from the relation:

$$
\text { Frequency }=\frac{\text { Number of quadrats }(20 \mathrm{~m} \times 20 \mathrm{~m}) \text { in which a particular species occurred }}{\text { Total number of quadrats }(500 \text { quadrats })} \times 100
$$

\subsection{Diversity of Plant Species}

The diversity of the plant species was determined using Shannon-Weiner (1949) and Simpson's (1949) indices.

Shannon-Weiner Index, H:

$$
\mathrm{H}=-\sum \mathrm{Pi} \ln \mathrm{Pi}
$$

Where, $\mathrm{Pi}=\mathrm{ni} / \mathrm{N}$

and $\mathrm{ni}=$ number of individuals of the $\mathrm{i}^{\text {th }}$ species

$\mathrm{N}=$ total number of individuals

Simpson's Index, D:

$\mathrm{D}=1-\mathrm{C}$

Where, $\mathrm{C}=$ Concentration of Dominance

$=\sum \mathrm{ni}(\mathrm{ni}-1) / \mathrm{N}(\mathrm{N}-1)$

Where ni and $\mathrm{N}$ are defined as above

2.9 Species Evenness (E)

$\mathrm{E}=\mathrm{H} 1 / \operatorname{lnS}$ (Pielou, 1969)

Where, $\mathrm{H}^{1}=$ Shannon - Weiner diversity index

$\mathrm{S}=$ number of species 


\subsection{Similarity of Species}

The similarity of species between the mined and unmined areas was obtained using Sorenson's Index and Similarity Ratio.

The Sorenson's index for this study was obtained from the relation:

$$
\mathrm{Ss}=\frac{2 a}{(2 a+b+c)}
$$

Where;

$\mathrm{a}=$ number of species common to both mined and unmined study sites

$\mathrm{b}=$ number of species unique to mined site

$\mathrm{c}=$ number of species unique to unmined site

2.11 Similarity Ratio (SR)

The similarity between species in mined site (a) and unmined site (b) was obtained from the relation:

$$
\mathrm{SRij}=\frac{\sum \mathrm{KYKaYKb}}{\left(\sum \mathrm{KYKa}^{2}+\sum \mathrm{KYKb}^{2}-\sum \mathrm{KYKaYKb}\right)}
$$

Where;

$\mathrm{KYKa}=$ abundance of $\mathrm{K}^{\text {th }}$ species in mined site

$\mathrm{KYKb}=$ abundance of $\mathrm{K}^{\text {th }}$ species in unmined site

\subsection{Pioneer Index (PI)}

The Pioneer Index of plant species for each of the study sites was obtained from the relation:

$$
\text { PI }=\frac{(\text { Pioneers } \times \text { Pioneer Weight })+(\text { NPLD } \times \text { NPLD Weight }) \times 100}{\text { Total Number }(\text { of individuals of species sampled })}
$$

Where;

Pioneer weight $=2 ;$ NPLD weight $=1$ (Hawthorne, 1993).

Pioneers - Number of Pioneer species

NPLD - Number of NPLD species

2.13 Genetic Heat Index (GHI)

The Genetic Heat Index for species in each of the study sites (mined and unmined) was obtained from the relation:

$$
\mathrm{GHI}=\frac{(B K \times B K w e i g h t)+(G D \times G D w e i g h t)+(B U \times B U w e i g h t)+(R D \times R D w e i g h t) \times 100}{B K+G D+B U+G N+R D}
$$

Where;

$\mathrm{BK}, \mathrm{BU}, \mathrm{GD}, \mathrm{GN}$ and RD represent Black, Blue, Gold, Green and Red species respectively

BK weight is the weight of black species etc.

Weights of black, gold, blue, red and green species are 27, 9, 3, 1 and 0 respectively (Hawthorne, 1993).

2.14 Economic Index (E)

The economic index for species in each of the study areas (mined and unmined) was obtained from the relation:

$$
\mathrm{EI}=\frac{(S C \times S C \text { weight })+(R D \times R D \text { weight })+(P K \times P K \text { weight }) \times 100}{\text { Total all stars }}
$$

Where;

$\mathrm{SC}$ is scarlet; $\mathrm{RD}$ is red and $\mathrm{PK}$ is pink.

Weight of scarlet $=3 ;$ red $=2 ;$ pink $=1$ (Hawthorne, 1993) 
The plant species were grouped into star ratings to reflect genetic conservation value. The star classification provides a priority list for species. It also highlights the "genetic hot-spots" of the plant community. In this study, the plant species were star-rated according to the specific circumstances of Ghana as follows:

\section{Black star}

Species are rare internationally and at least uncommon in Ghana;

urgent attention to conservation of population needed.

\section{Gold star}

Species are fairly rare internationally and / or locally.

\section{Blue star}

Species are widespread internationally but rare in Ghana or vice-versa.

\section{Pink star}

Species are common and moderately exploited. Also non- abundant species of potential value.

\section{Red star}

Species are common but under serious pressure from exploitation.

Current rate of exploitation if not controlled can lead to economic damage in the next few years.

\section{Scarlet star}

Species are common but under extreme pressure from heavy exploitation. Presently, economic damage from heavy exploitation being experienced.

\section{Green star}

Species of no particular conservation concern and are common in Ghana.

\section{Results}

\subsection{Assessment of Flora in Mined and Unmined Sections of the Study Area}

Two hundred and seventy eight plant species belonging to 238 genera and 84 families were identified in mined and unmined study areas (Table 1). The Magnoliopsida (Dicots) emerged with $80.21 \%$ of the species distributed among six subclasses and was the most dominant group in terms of number of species. The Liliopsida (Monocots) followed with a dominance of $15.83 \%$ of the species distributed among four subclasses. The plant group with the least number of species was the Pteridophyta which accounted for $3.96 \%$ of the total species.

Table 1. Plant groups of the flora in the unmined and mined study areas

\begin{tabular}{llll}
\hline Plant group & Number of families & Number of genera & Number of species \\
\hline Magnoliopsida & 63 & 188 & 223 \\
Liliopsida & 13 & 42 & 44 \\
Pteridophyta & 8 & 8 & 11 \\
Totals & $\mathbf{8 4}$ & $\mathbf{2 3 8}$ & $\mathbf{2 7 8}$ \\
\hline
\end{tabular}

The Magnoliopsida (Dicots) consisted of plant species from six subclasses which were the Magnoliidae, Asteridae, Rosidae, Dillenidae, Caryophyllidae and Hamamelidae. The dicot with the most number of species was the Rosidae which accounted for $30.93 \%$ of all the species encountered (Figure 2). This was followed by the Asteridae $(27.33 \%)$ and the Dillenidae (11.87\%). In order of decreasing number of species, the contributions of the remaining subclasses of the dicots were Hamamalidae (4.68\%), Magnoliidae (2.88\%) and Caryophyllidae (2.52\%). The monocots were distributed in four subclasses; namely, Commelinidae, Arecidae, Zingiberidae and Liliidae and their contribution to the total number of species encountered in the study were $10.43 \%, 2.52 \%, 1.80 \%$ and $1.08 \%$, respectively. The Pteridophyta group formed $3.96 \%$ of the total number of plant species obtained in the study (Figure 2). 


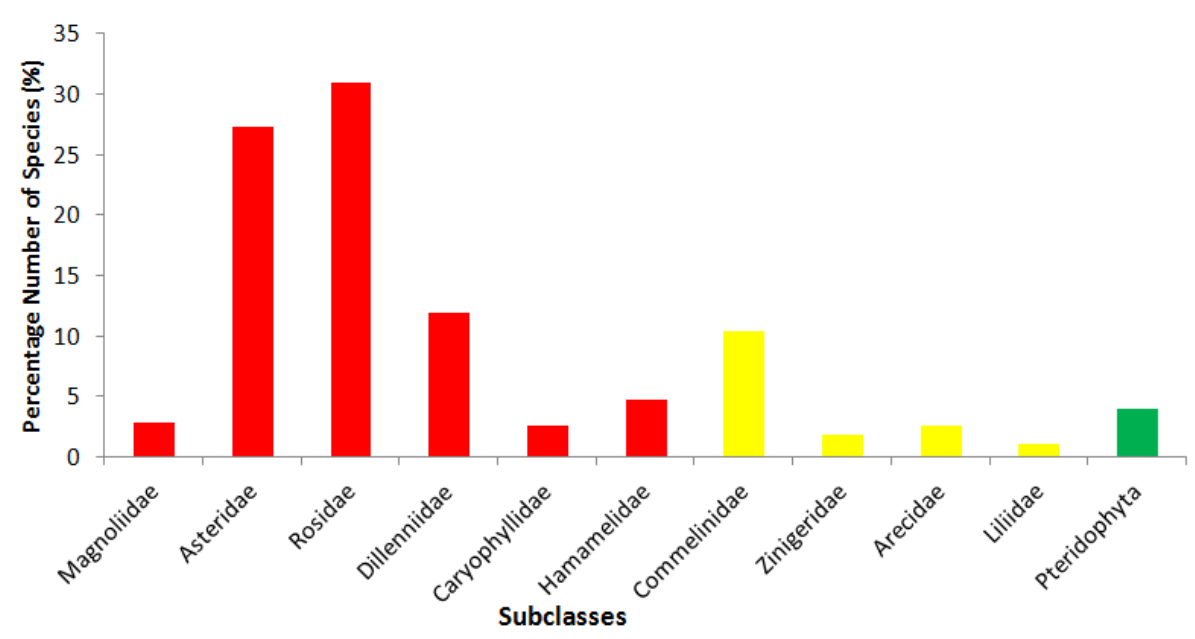

Figure 2. Distribution of plant species among taxonomic groups

One hundred and fifty seven species found in 140 genera and 54 families were identified in the mined study area whilst 209 species encountered in the unmined study area were distributed in 185 genera and 73 families. Eighty-eight (88) plant species identified in this study were common to both the mined and unmined areas. The number of plant species found in only the mined site was 69 species and that for the unmined site was 121 species.

\subsection{Distribution and Abundance of Plant Species in the Unmined and Mined Study Areas}

The prevalence of the species in the unmined area ranged from $0.2 \%$ to $20.6 \%$. The species with relatively higher frequencies in the unmined area included Spilanthes filicaulis (20.6\%), Pteridium aquilinium (18.6\%), Diplazium sammatii (17.6\%), Sorghum arundinaceum (17.6\%), Chromoleana odorata $(17.0 \%)$ and Tridax procumbens (16.6\%). Other plants species of low frequency found in the unmined site included Theobroma cacao (1.0\%), Aningera altissima $(0.2 \%)$, Ochna staudii $(0.2 \%)$ and Zanthoxylum lemairei $(0.4 \%)$. The distribution of species in the mined area ranged between $58.4 \%$ and $0.2 \%$. Plant species which were relatively better distributed in the mined area included Chromolaena odorata (54.8\%), Echninochloa cruspavanis (54.0\%), Helleria latifolia (51.4\%), Euphorbia hirta (46.2\%), Momordica charantia (46.2\%) and Sporobolus pyramidalis (45.4\%). Other species of low distribution in the mined area included Cola chlamydantha $(0.2 \%)$, Solanum eranthium $(0.4 \%)$, Treculia africana ( $0.4 \%)$ and Cyclosorus afer $(0.6 \%)$. The densities of species in the unmined area were generally low. Plant species with relatively higher density values included Pteridium aquilinum (0.22), Tridax procumbens (0.19), Waltheria indica (0.17), Euphorbia hirta (0.15), Chromolaena odorata (0.15) and Grewia pubescens (0.14). Species with least density value of 0.01 in the unmined area included Ochna staudii and Aningeria altissima. The values for the density of species in the mined area ranged from 0.01 to 4.37 . Plant species such as Chromolaena odorata (4.37), Sporobolus pyramidalis (2.14), Echinochloa cruspavonis (1.50), Panicum maximum (1.40) and Commelina benghalensis (1.35) had relatively higher density values in the mined area. Solanum erianthum (0.01), Hallea ledermannii (0.01), Cyclosorus afer (0.02), Berhinia occidentalis (0.02) and Antiaris africana (0.02) had low density values.

\subsection{Overview of Plant Life Forms in the Unmined and Mined Areas}

Six plant life forms were recognized amongst the species in the unmined study area (Table 2). These were trees, herbs, shrubs, climbers, lianes and ferns. The group with the highest number of species in the unmined study area was the trees which accounted for $52.15 \%$ of all the species encountered (Table 2). The herbs followed with $27.75 \%$ of the species. The next group of species was the climbers which comprised $9.09 \%$ of the species. Following the climbers were the ferns, lianes and shrubs with $4.31 \%, 3.83 \%$ and $2.87 \%$ of the species, respectively (Table 2 ). 
Table 2. Life form of plant species growing in the unmined study area

\begin{tabular}{lll}
\hline Life form & Number of species & Proportion of species (\%) \\
\hline Tree & 109 & 52.15 \\
Herbs & 58 & 27.75 \\
Shrub & 6 & 2.87 \\
Climber & 19 & 9.09 \\
Liane & 8 & 3.83 \\
Fern & 9 & 4.31 \\
Total & $\mathbf{2 0 9}$ & $\mathbf{1 0 0}$ \\
\hline
\end{tabular}

In the mined study area, eight life forms were recognized amongst the species (Table 3). These were trees, herbs, shrubs, climbers, seedlings of trees, lianes, ferns and saplings. The dominant plant life form was the herb, constituting $56.05 \%$ of all the species in the mined area. The climbers followed with $12.01 \%$ of the species identified. Next to the climbers were the trees and saplings accounting for $9.56 \%$ and $8.28 \%$ of the species, respectively. These were followed by the shrubs, involving $6.37 \%$ of the species. The next group of species was the tree seedling which came up with $3.82 \%$ of the species encountered. Following the tree seedlings were the lianes and ferns. Each group accounted for $1.91 \%$ of the species in the mined area (Table 3).

Table 3. Life form of plant species growing in the mined study area

\begin{tabular}{lll}
\hline Life form & Number of species & Proportion of species (\%) \\
\hline Tree & 15 & 9.56 \\
Herb & 88 & 56.05 \\
Shrub & 10 & 6.37 \\
Climber & 19 & 12.10 \\
Seedling (of a tree) & 6 & 3.82 \\
Liane & 3 & 1.91 \\
Fern & 3 & 1.91 \\
Sapling & 13 & 8.28 \\
Total & $\mathbf{1 5 7}$ & $\mathbf{1 0 0}$ \\
\hline
\end{tabular}

\subsection{Ecological Status of Plant Species in the Unmined and Mined Study Areas}

The ecology of the species with respect to the presence of canopies and gaps and other influences on the flora showed that the dominant guild in the unmined plant community was the Pioneers, forming $44.98 \%$ of all the species (Table 4). The Non-Pioneer Light Demanding (NPLD) and the Shade bearers constituted $16.27 \%$ and $13.87 \%$ of the species, respectively. The least guild identified in the unmined study area was the Swamp (1.91\%). The guilds of 48 plant species (forming $22.97 \%$ of identified species) were not available (Table 4 ).

Table 4. Ecological guild of plant species growing in the unmined area

\begin{tabular}{lll}
\hline Ecological guild & Number of species & Proportion of species (\%) \\
\hline Pioneer & 94 & 44.98 \\
Shade bearer & 29 & 13.87 \\
Non-Pioneer Light Demanding & 34 & 16.27 \\
Swamp & 4 & 1.91 \\
Not Available & 48 & 22.97 \\
Total & $\mathbf{2 0 9}$ & $\mathbf{1 0 0}$ \\
\hline
\end{tabular}

The guild of species in the flora of the mined study area showed that Pioneers formed $59.24 \%$ of the species (Table 5). The remaining guilds, Shade bearers, Non-Pioneer Light Demanding and Swamps showed up as 6.37\%, 5.73\% and $1.27 \%$ of the species, respectively. The guild of $27.39 \%$ of the species encountered in the mined area was not available (Table 5). 
Table 5. Ecological guild of plant species growing in the mined area

\begin{tabular}{lll}
\hline Ecological guild & Number of species & Proportion of species (\%) \\
\hline Pioneer & 93 & 59.24 \\
Shade Bearer & 10 & 6.37 \\
Non-Pioneer Light Demanding & 9 & 5.73 \\
Swamp & 2 & 1.27 \\
Not Available & 43 & 27.39 \\
Total & $\mathbf{1 5 7}$ & $\mathbf{1 0 0}$ \\
\hline
\end{tabular}

\subsection{Diversity of Plant Species in the Unmined and Mined Study Areas}

The diversity of species in the unmined area was found to be high (Table 6). The Shannon-Weiner Index gave a mean value of $4.62 \pm 0.025$ whilst the Simpson's Index gave a mean value of $0.98 \pm 0.012$. The Evenness of the species had a mean value of $0.52 \pm 0.015$.

Table 6. Diversity of plant species in the unmined study area

\begin{tabular}{lllllll}
\hline & \multicolumn{9}{c}{ Quadrat $(\mathbf{2 0 0} \times \mathbf{2 0 0 m})$ Number } & \multicolumn{2}{c}{ Mean } \\
\hline Diversity Index & $\mathbf{1}$ & $\mathbf{2}$ & $\mathbf{3}$ & $\mathbf{4}$ & $\mathbf{5}$ & $4.62 \pm 0.025$ \\
Shannon-Weiner $\left(\mathrm{H}^{1}\right)$ & 4.64 & 4.62 & 4.65 & 4.60 & 4.59 & $0.98 \pm 0.012$ \\
Simpson's (D) & 0.99 & 0.98 & 0.96 & 0.98 & 0.99 & $0.51 \pm 0.015$ \\
Evenness (E) & 0.50 & 0.53 & 0.52 & 0.54 & 0.51 & \\
\hline
\end{tabular}

The diversity of plant species in the mined area was also high. The Shannon-Weiner Index gave a mean value of $4.54 \pm 0.023$ whilst the Simpson's Index had a mean value of $0.98 \pm 0.014$ (Table 7). The mean value for the Evenness of the species was $0.40 \pm 0.012$.

Table 7. Diversity of plant species in the mined study area

\begin{tabular}{lllllll}
\hline & \multicolumn{9}{c}{ Quadrat (200m $\times \mathbf{2 0 0 m})$ Number } & \multicolumn{2}{l}{ Mean } \\
\hline Diversity Index & $\mathbf{1}$ & $\mathbf{2}$ & $\mathbf{3}$ & $\mathbf{4}$ & $\mathbf{5}$ & $4.54 \pm 0.023$ \\
Shannon-Weiner $\left(\mathrm{H}^{\mathrm{I}}\right)$ & 4.50 & 4.56 & 4.55 & 4.55 & 4.54 & $0.98 \pm 0.014$ \\
Simpson's (D) & 0.97 & 0.99 & 0.96 & 0.99 & 0.99 & $0.40 \pm 0.012$ \\
Evenness (E) & 0.39 & 0.40 & 0.39 & 0.40 & 0.42 & \\
\hline
\end{tabular}

\subsection{Star - Rating of Plant Species in the Unmined and Mined Study Areas}

The star-rating of the plant species in the unmined study area showed that there were no black star species (Table 8 ). However, blue (3.83\%), gold (1.91\%), green $(52.15 \%)$, red (3.83\%), pink (7.18\%) and scarlet $(2.87 \%)$ species were recorded. The study revealed the dominance of green star species in the unmined area. Fifty-nine (59) species forming $28.23 \%$ of the plant species identified in the unmined area have not been star-rated (Table 8 ).

Table 8. Star - rating of plant species growing in the unmined area

\begin{tabular}{lll}
\hline Star - rating & Number of species & Proportion of species (\%) \\
\hline Blue & 8 & 3.83 \\
Scarlet & 6 & 2.87 \\
Gold & 4 & 1.91 \\
Red & 8 & 3.83 \\
Pink & 15 & 7.18 \\
Green & 109 & 52.15 \\
Not Available & 59 & 28.23 \\
Total & $\mathbf{2 0 9}$ & $\mathbf{1 0 0}$ \\
\hline
\end{tabular}


The conservation status of species in the mined area revealed that most of the species $(59.87 \%)$ were not star-rated (Table 9). Out of the 63 species which were star-rated, 53 species were green $(33.76 \%)$. The star- ratings of the other species showed up as blue (0.64\%), scarlet (0.64\%), gold (0.64\%), red (1.91\%) and pink $(2.54 \%)$. The blue, scarlet, gold, red, and pink star-rated species were distributed in 10 plant species in the mined area (Table 9) and also found in 41 species in the unmined area (Table 8).

Table 9. Star - rating of plant species growing in the mined study area

\begin{tabular}{lll}
\hline Star - rating & Number of species & Proportion of species (\%) \\
\hline Blue & 1 & 0.64 \\
Scarlet & 1 & 0.64 \\
Gold & 1 & 0.64 \\
Red & 3 & 1.91 \\
Pink & 4 & 2.54 \\
Green & 53 & 33.76 \\
Not Available & 94 & 59.87 \\
Total & $\mathbf{1 5 7}$ & $\mathbf{1 0 0}$ \\
\hline
\end{tabular}

\subsection{Some Indices of Plant Species in the Unmined and Mined Study Areas}

The analysis of the Shannon-Weiner $\left(\mathrm{H}^{1}\right)$ diversity values for the unmined and mined study areas showed that the $\mathrm{t}$-statistic of the $\mathrm{H}^{1}$ - diversity was -5.16 and the P-value was 0.001 . There was a significant difference $(\mathrm{p}<0.05)$ between the $\mathrm{H}^{1}$ - unmined and $\mathrm{H}^{1}$-mined Shannon $\left(\mathrm{H}^{1}\right)$ values (Table 10$)$.

Table 10. Indices of plant species in the unmined and mined study areas

\begin{tabular}{lllll}
\hline Index & Mined & Unmined & T-Test & P-value \\
\hline GHI All Star & $31.84 \pm 1.44$ & $59.33 \pm 0.50$ & -40.37 & 0.000 \\
GHI Trees Only & $54.89 \pm 1.46$ & $64.42 \pm 0.63$ & -13.41 & 0.000 \\
EI All Star & $20.88 \pm 1.75$ & $32.66 \pm 0.93$ & -13.27 & 0.000 \\
EI Trees Only & $41.84 \pm 3.07$ & $46.15 \pm 0.89$ & -3.02 & 0.039 \\
PI & $137.48 \pm 2.89$ & $132.77 \pm 1.76$ & -3.12 & 0.021 \\
Shannon & $4.62 \pm 0.025$ & $4.54 \pm 0.023$ & -5.16 & 0.001 \\
\hline
\end{tabular}

For both the Genetic Heat Index (GHI) and Economic Index (EI) of all-star-rated species, there were significant differences $(p<0.05)$ between the GHI's and EI's of plant species of the unmined and mined sites (Table 10). The analysis of the GHI and EI of only trees in the study area showed that there were significant differences between the GHI's and the EI's of the plant species in the unmined and mined areas (Table 10). The analysis of the Pioneer Index (PI) values for the flora of the unmined and mined areas showed that the t-statistic was -3.12 and the P-value was 0.021 indicating a significant difference $(\mathrm{p}<0.054)$ between PI of species in the unmined and mined areas (Table 10).

\subsection{Similarity of the Flora of the Unmined and Mined Study Areas}

Comparative study of the flora of the unmined and mined study areas showed that the Similarity ratio (SR) was 0.033519 and the Sorenson's Index (SI) was 0.4808 .

\section{Discussion}

\subsection{Floral Richness and Diversity at the Study Site}

The unmined study area had more floral species (209 species distributed in 185 genera and 73 families) than the mined area (157 species distributed in 140 genera and 54 families). This suggested that intact moist semi-deciduous forests (unmined area) had flora with many different species and relatively few individuals in each species (Fonge, Tchetcha, \& Nkembi, 2013; Pappoe, Armah, Quaye, Kwakye, \& Buxton, 2010) than semidisturbed or disturbed forest (mined area). Moreover, intact tropical forest ecosystems tend to have plant species diversity reserves as observed by Kothandaram \& Sundarapandian (2017). In this study, 69 species were found growing only in the mined area. The loss of canopy and creation of gaps in the mined area could have led to growth of many secondary plant species, especially herbs (Sahoo, Panda, \& Acharya, 2017). This could have accounted 
for the 84,246 individuals distributed in 157 species in the mined area and the 6745 individuals distributed in 209 species in the unmined area. According to Sundarapandian \& Karoor (2013), environmental and anthropogenic changes in forest ecosystems affect plant community structure and species composition.

The dominant plant families in the unmined area were the Euphorbiaceae (18species), Rubiaceae (18species) and Asteraceae (10species); and that of the mined area were Poaceae (22species), Euphorbiaceae (17species) and Asteraceae (11species). This conformed with observations by Duah-Gyamfi, Kyereh, Adam, \& Swaine, (2014) who noted that the Euphorbiaceae, Rubiaceae and Moraceae were among the five dominant families in their study of a tropical forest in Ghana. In another study conducted on plant species in a tropical West African forest in Sierra Leone National Park (Gola Rainforest National Park), the Fabaceae, Euphorbiaceae and Sterculiaceae families were dominant (Laurin et al., 2013). According to Kothandaraman \& Sundarapandian (2017), the Euphorbiaceae was the dominant plant family in two forest areas in the tropical deciduous forest of Kanyakumari Wildlife Santuary in India. The Papilionaceae, Moraceae, Sterculiaceae and Sapindaceae were listed as the dominant plant families in a tropical forest ecosystem in south-western Nigeria (Eludoyin, Ojo, Ojo, \& Awotoye, 2017). According to a study done by Naidu \& Kumar (2016) and Sundarapandian \& Karoor (2013) on tropical forest ecosystems, the Euphorbiaceae and Combretaceae were the top-most contributors to species diversity while the Poaceae and Fabaceae were most dominant families in terms of abundance. In this study, the Euphorbiaceae, Rubiaceae and Asteraceae contributed most to species diversity while Asteraceae, Poaceae and Euphorbiaceae were abundant in both the unmined and mined areas. High species richness is typical of many tropical forests (Antonelli \& Sanmartin, 2011; Tarakeswara, Premavani, Suthari, \& Venkaiah, 2018). The most dominant tree families encountered in the unmined area were the Euphorbiaceae (12 species distributed in 10 genera) and Rubiaceae with 10 species distributed in 9 genera. This observation is in agreement with the findings by Fonge et al. (2013) and Attua \& Pabi (2013) who stated that the Rubiaceae was the dominant tree family in tropical forests in Mount Cameroon and Northern Forest -Savanna Ecotone of Ghana respectively. Laurin et al. (2013) in their study on a tropical West African forest in Sierra Leone National Park (Gola Rainforest National Park), identified the Euphorbiaceae, Fabaceae and Sterculiaceae as dominant tree families. The marked presence of the Euphorbiaceae and Rubiaceae in the unmined area is a feature common to most tropical forests (Ifo et al., 2016) however, this observation contradicts the findings of Pappoe et al. (2010) who identified the Meliaceae, Sterculiaceae, Mimosaceae and Moraceae as dominant tree families in a study conducted in the tropical forest of the Kakum National Park in Ghana. The study site with relatively higher species richness was the unmined area with Margalef richness value of 23.53 whiles the mined site had a Margalef richness value of 13.75 .

The significant difference $(\mathrm{p}<0.05)$ between the $\mathrm{H}^{1}$-unmined and $\mathrm{H}^{1}$ mined (Table 10) could indicate that the two areas are environmentally different from each other (Magurran, 2013) and this could have influenced the observed lower similarity of plant species (Sorenson's index $=0.48 .8$; Similarity ratio $=0.033519$ ) between the unmined and mined areas. The $\mathrm{H}^{1}$ for both unmined and mined areas (Table 10) were higher than 3.5 indicating that despite the anthropogenic activities (small-scale mining, farming etc.) in the study area, plant species diversity has not been adversely altered much (Fonge et al., 2013). The equitability and Simpson's diversity of ( 0.50 to 0.54 ) and ( 0.96 to 0.99 ) in the unmined area (Table 6), imply that between $50 \%$ to $54 \%$ of the species were equitably distributed in the unmined area (Magurran \& Henderson, 2003; Pappoe et al., 2010) while between $96 \%$ to $99 \%$ of the species in the flora may be of different species. Thirty-nine to forty-two percent of the plant species were equitably distributed in the mined area, while between $97 \%$ and $99 \%$ of the species in the mined flora may be of different species (Table 7). The relatively lower diversity in the mined area was probably due to anthropogenic activities such as small-scale mining, farming and hunting (Fonge et al., 2013). Work done by Tom-Dery, Dagben, and Cobbina (2012) in Northern Ghana indicated that small-scale mining activities caused reduction in the diversity of plant species. The unmined area is dominated by trees (52.15\%) and tropical trees tend to be highly species diverse (Pappoe et al., 2010). The diversity in tropical trees is due to habitat suitability, differences in biogeography and anthropogenic pressures (Sundarapandian \& Karoor, 2013).

\subsection{Species Distribution, Abundance and Conservation Status}

The distribution of the species into life forms in the unmined area showed that trees were the most dominant (52.15\%) followed by herbs with $27.75 \%$ of the species (Table 2). The dominance of tree species in the unmined area is typical of the ecosystem under study (Magurran, 2013). It was also observed that the dominant life forms in the mined area were the herbs (56.06\%) which were followed by climbers with $12.10 \%$ of the species (Table 3 ). The observed differences in the vegetation structure of the two areas could be due to edaphic and anthropogenic (small-scale mining) characteristics (Kothandaraman \& Sundarapandian, 2017). The significant difference $(p<0.05)$ between the pioneer index $(\mathrm{PI})$ values of the species in the unmined and mined areas (Table 10) indicate relatively heavy disturbance of the flora of the mined area. A high pioneer index value gives a good indication of 
the "secondariness" of an area of a forest and most forests in Ghana are secondary in terms of species composition (Hawthorne \& Gyakari, 2006). This finding corroborated with Tchouto (2004) who observed in Cameroon tropical forest that the numbers of herbaceous species and climbers increase with the degree of floral disturbance. Gyamfi, Swaine, Adam, and Pinard (2014) also found out that after anthropogenic disturbances of the flora in a tropical ecosystem, the numbers of pioneer species (especially herbs) are expected to increase. The relative high number of herbs found in the mined area as compared to the unmined area (Tables 2 and 3) suggest that more time is needed for the expected flora compositional shift to take place naturally (Oduro et al., 2012).

The species richness of a forest ecosystem depends on the number of species per unit area. The situation where there are more species per unit area, the species richness tends to be high (Eludoyin et al., 2017). The species richness values of 82 tree species/ha for the unmined area and 7 tree species/ha for the mined area were lower as compared to 552 tree species/ha obtained in a tropical forest in Kade in Ghana (Hall \& Swaine, 1981) and 93 tree species/ha observed in a tropical forest in Tanzania (Kacholi, 2014). Phillips, Hall, Gentry, Sawyer, and Vasquez (1994) after analysis of different tropical forests indicated that the average tree species richness were 86-92 tree species/ha and 56 trees species/ha for Ghana and Uganda, respectively. Studies conducted on species diversity of three Ghanaian tropical forest reserves by Gatti, Laurin, and Valentini (2017) showed that the Bia and Dadieso forests had tree species richness of 88-118 trees/ha which was similar to tree species richness of other Ghanaian forests. However, the species richness of trees obtained from the unmined study area (82 tree species/ha) was higher than the 60-70 tree species/ha (Lawson, 1985), and 28 tree species/ha (Addo-Fordjour, Obeng, Anning, \& Addo, 2009) obtained in West African Tropical Forests.

The significant difference $(\mathrm{p}<0.05)$ between GHI's of all star-rated/trees species (Table 10) of the unmined and mined areas shows that the level of destruction of species of high conservation value is more pronounced in the mined area and the unmined area relatively has more exciting and rare species (Hawthrone \& Jongkind, 2006). This could have accounted for the significant differences $(\mathrm{p}<0.05)$ observed between the Economic index $(\mathrm{EI})$ values of all star species and that of trees only between the unmined and mined areas (Table 10), indicating that species in the unmined areas have higher commercial and conservation value than that of the mined areas. The GHI of trees $(64.42 \pm 0.63)$ for the unmined area (Table 10) shows that generally, the forest ecosystem of the study area falls in the low conservation or bioquality category (Hawthorne \& Abu-Juam, 1995) and this has implications for biodiversity conservation in the study area. The study showed a decline in tree species richness and diversity in the mined area and this could be attributed to small-scale mining activities. According to Swamy et al. (2010), many tropical forests have lost the potential for self-maintenance due mainly to anthropogenic activities. Small-scale mining activities at the mined site could have altered the ecological factors over the area leading to the differences in the diversity, density and distribution of plant species between the unmined and mined areas (Khan et al., 2017).

The presence of many species with low density and frequency values in the unmined area could be due to the fact that most of the plant species are rare (Magurran, 2013). The rarity of majority of the species in the unmined area may be due to strong density-dependency in the area, poor dispersal of species and the presence of resource gradient leading to abundance distribution variation of species (Fonge et al., 2013; Naidu, Premavani, Suthari, \& Venkaiah, 2018).

The anthropogenic disturbances as a result of small-scale mining probably led to the destruction of canopies and creation of gaps in the mined area leading to the preponderance of herbaceous species with relatively higher densities and frequencies (Table 8). The floristic richness of species in a forest zone could be influenced by the geographical location of the area, favourable climatic conditions and the level of anthropogenic disturbances (Eludoyin et al., 2017; Laurin et al., 2013).

The classification of all plant species into guilds in the study area showed that Pioneers had 187 species, Non-Pioneer Light Demanding (NPLD) obtained 43 species, Shade-Bearers consisted of 39 species and 6 species were found in the Swamp ecological category (Tables 4 and 5). The totality of Pioneers and NPLD (230 species) in the study area could underpin the existence of gaps in the study area (Hawthorne, 1993). The relative abundance of Pioneers and NPLD in the unmined area (128 species) as compared to the 102 species (Pioneers and NPLD) in the mined area (Tables 4 and 5), could be due to the dominance of tree species (109 species) in the unmined area as compared to the 15 tree species in the mined area (Tables 2 and 3). According to Hawthorne and Abu-Juam (1995) and (Hawthorne, 1993), most lianes and timber species (trees) are NPLD and Pioneers.

\subsection{Use of Native Plant Species for Rehabilitation of Mined Area}

The knowledge on regeneration status of native plant species in any human-modified forest ecosystem is critical for the determination of the structure and composition of future communities in the ecosystem (Lasky et al., 2014). 
As noted by Loo et al. (2017), regeneration of native tree species has a good occurrence in human- modified forest where native tree species can be recruited from the remnants of the surrounding forest.

In this study, native tree species of relatively good abundance and distribution that could be exploited for regeneration in the mined area included Macaranga hurifolia, Macaranga barteri, Macaranga heterophylla, Vernonia conferta, Pentaclethra macrophylla, Calycobolus africanus, Alchornea cordifolia, Carapa procera, Allanblackia floribunda, Pachystella brevipes, Baphia nitida and Piptadeniastrum africanum. Native species identified for the restoration of degraded forests in Offinso in Ghana included Milicia excelsa, Piptadeniastrum africanum, Entandrophragma angolense, Pericopsis elata, Pouteria sp., Terminalia superba, Terminalia ivoriensis, Entandrophragma utile and Antiaris toxicaria (Mensah, 2015). The native species identified by for regeneration of degraded forests in Offinso are generally different from that in the findings of this study. As recommended by Brown \& Amacher (1999) and Morgan (2005), a study of the neighbouring areas surrounding a degraded forest site, provides an indication of what native species are more likely to survive and thrive in soils of the local area and be useful for any planned restoration programme. The use of mixed native tree species generally promotes and accelerates the plant species restoration process in a degraded tropical forest (Baatuuwie \& Van Leeuwen, 2011).

\section{Conclusion}

The study on the flora of the unmined and mined areas has revealed that small-scale mining has contributed to the reduced numbers of plant species of higher conservation value in the mined areas; caused reduction in species diversity and richness; reduced the economic and commercial value of species in the mined area; and increased destruction of canopies leading to the preponderance of herbaceous species in the mined areas. The study provides important information on the abundance and distribution of plant species (especially tree species) which can be targeted and prioritized and used for the formulation of site-specific strategies for conservation of biological diversity and restoration of degraded/mined areas in a moist semi-deciduous forest located in the environs of Dunkwa East Municipality of Ghana. The study area is very rich and diverse in terms of plant species and the species in the unmined area are richer and more diverse than that of mined area. Plant families Euphorbiaceae, Rubiaceae and Asteraceae were the top-most contributors to species diversity whilst the Asteraceae, Poaceae and Euphorbiaceae were dominant in terms of abundance in the unmined area; and in the mined area the Poaceae, Euphorbiaceae and Asteraceae contributed most to diversity and abundance of species. Species wise, Pteridium aquilinum, Tridax procumbens and Waltheria indica in the unmined area and Chromolaena odorata, Sporobolus pyramidalis and Euphorbia hirta in the mines area were dominant. Trees and herbs were prominent in the unmined area whilst herbs and climbers were dominant in the mined areas. The rehabilitation of small-scale mined site at the study area should necessary include planned regeneration of plant species for sustainability of the mined environment. Macaranga hurifolia, Macaranga barteri, Macaranga heterophylla, Vernonia conferta, Pentaclethra macrophylla, Calycobolus africanus, Alchornea cordifolia, Carapa procera, Allanblackia floribunda, Pachystella brevipes, Baphia nitida and Piptadeniastrum africanum could be exploited for regeneration in the mined area.

\section{Acknowledgements}

I would also like to express my sincere gratitude to Prof. Frederick Ato Armah for his invaluable contributions and encouragement to make this work better. I wish to thank the staff of the Herbarium at University of Cape Coast for their advice on identification of plant species. I gratefully acknowledge the assistance provided by Messrs Joseph Kennetey, Akwasi Agyen, Kwame Owusu Yeboah and Kwadwo Ofori for their contributions throughout the period that this work was carried out.

\section{Conflict of interests}

The authors declare that there is no conflict of interests regarding the publication of this paper.

\section{References}

Addo-Fordjour, P., Obeng, S., Anning, A. K., \& Addo, M. G. (2009). Floristic composition, structure and natural regeneration in a moist semi-deciduous forest following anthropogenic disturbances and plant invasion. International Journal of Biodiversity and Conservation, 1(2), 021-037.

Antonelli, A., \& Sanmartin, I. (2011). Why are there so many plant species in the neotropics? Taxon, 60(2), 403-414.

Arthur, F., Agyemang-Duah, W., Gyasi, R. M., Yeboah, J. Y., \& Otieku, E. (2016). Nexus between artisanal and small-scale gold mining and livelihood in prestea mining region, ghana. Geography Journal, 18. 
Attua, E. M., \& Pabi, O. (2013). Tree species composition, richness and diversity in the northern forest-savanna ecotone of ghana. Journal of Applied Biosciences, 69, 5437-5448.

Baatuuwie, N. B., \& Van Leeuwen, L. (2011). Evaluation of three classifiers in mapping forest stand types using medium resolution imagery: A case study in the offinso forest district, ghana. African Journal of Environmental Science and Technology, 5(1), 25-36.

Benkenstein, A. (2012). Artisanal and small-scale mining in africa: Opportunities and challenges. Retrived from

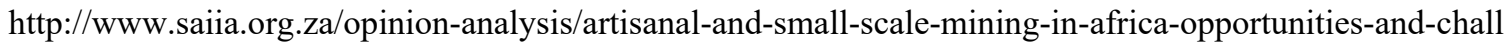
enges.

Brown, R. W., \& Amacher, M. C. (1999). Selecting Plant Species for Ecological Restoration: A Perspective for Land Managers. Proceedings from the United States Department of Agriculture, Forest Service. Washington, DC, USA: USDA, Forest Service.

Carvalho, P. (2017). Mining industry and sustainable development: Time for change. Food and Energy Security, $6(2), 61-77$.

Duah-Gyamfi, A., Kyereh, B., Adam, A. K., \& Swaine, M. D. (2014). Natural regeneration dynamics of tree seedlings on skid trails and tree gaps following selective logging in a tropical moist semi-deciduous forest in ghana. Open Journal of Forestry, 4(1), 49-57.

Dunkwa East Municipal Assembly (DEMA). (2014). Annual Report 2014. Accra, Ghana: Government Printer.

Edwards, D. P., Sloan, S., Weng, L., Dirks, P., Sayer, J., \& Laurance, W. F. (2014). Mining and the african environment. Conservation Letters, 7(3), 302-311.

Eludoyin, A. O., Ojo, A. T., Ojo, T. O., \& Awotoye, O. O. (2017). Effects of artisanal gold mining activities on soil properties in a part of southwestern nigeria. Cogent Environmental Science, 3(1), 1305650.

Fonge, B. A., Tchetcha, D. J., \& Nkembi, L. (2013). Diversity, distribution, and abundance of plants in lewoh-lebang in the lebialem highlands of southwestern cameroon. International Journal of Biodiversity.

Gatti, R. C., Laurin, G. V., \& Valentini, R. (2017). Tree species diversity of three Ghanaianreserves. Biogensciences and Forestry, 10, 362-368.

Gyamfi, A., Swaine, E. K., Adam, K. A., \& Pinard, M. (2014). Can harvesting for timber in tropical forest enhance timber tree regeneration? Forest Ecology and Management, 314, $26-37$.

Hall, J. B., \& Swaine, M. D. (1981). Distribution and ecology of vascular plants in tropical rainforest: Forest vegetation in ghana. Nertherlands: Springer

Hawthorne, W. D. (1993). Forest reserves of ghana: Graphical information exhibitor (froggie). Forest inventory and management Kumasi, Ghana: Ghana Forestry Department.

Hawthorne, W. D., \& Abu-Juam, M. (1995). Forest protection in ghana. Cambridge: Overseas Development Administration.

Hawthorne, W. D., \& Jongkind, C. C. H. (2006). Woody plants of western african forests, a guide to the forest trees, shrubs and lianes from senegal to ghana: Royal Botanic Gardens, Kew.

Hawthorne, W., \& Gyakari, N. (2006). Photoguide for the forest trees of ghana: A tree-spotter's field guide for identifying the largest trees. Oxford, UK: Oxford Forestry Institute, Department of Plant Sciences.

Hilson, G. (2002). Harvesting mineral riches: 1000 years of gold mining in ghana. Resources Policy, 28(1-2), $12-26$.

Ifo, S. A., Moutsambote, J.-M., Koubouana, F., Yoka, J., Ndzai, S. F., Bouetou-Kadilamio, L. N. O., ..., \& Loumeto, J. J. (2016). Tree species diversity, richness, and similarity in intact and degraded forest in the tropical rainforest of the congo basin: Case of the forest of likouala in the republic of congo.

Kacholi, D. S. (2014). Analysis of the kilengwe forest in the morogoro region, tanzania. International Journal of Biodiversity.

Khan, M., Khan, S. M., Ilyas, M., Algaraw, A. A., Ahmad, S., \& Elsayed, F. A. A. (2017). Plant species and communities assessment in interaction with edaphic and topographic factors; an ecological study of the mount eelum district swat, pakistan. Saudi J. Biol. Sci, 24(4), 778-786.

Kothandaraman, S., \& Sundarapandian, S. (2017). Structure of plant community in tropical deciduous forests of kanyakumari wildlife sanctuary, india. Biodiversitas Journal of Biological Diversity, 18(1). 
Kpan, J. D. A., Opoku, B. K., \& Anukwah, A. (2014). Heavy metal pollution in soil and water in some selected towns in dunkwa-on-offin district in the central region of ghana as a result of small scale gold mining. Journal of Agricultural Chemistry and Environment, 3(02), 40-47.

Kuranchie-Mensah, E. B., \& Amponsah-Tawiah, K. (2016). Employee motivation and work performance: A comparative study of mining companies in ghana. Journal of Industrial Engineering and Management, 9(2), 255-309.

Lasky, J. R., Uriarte, M., Boukili, V. K., Erickson, D. L., John Kress, W., \& Chazdon, R. L. (2014). The relationship between tree biodiversity and biomass dynamics changes with tropical forest succession. Ecology letters, 17(9), 1158-1167.

Laurin, G. V., Liesenberg, V., Chen, Q., Guerriero, L., Del Frate, F., Bartolini, A., .., \& Valentini, R. (2013). Optical and sar sensor synergies for forest and land cover mapping in a tropical site in west africa. International Journal of Applied Earth Observation and Geoinformation, 21, 7-16.

Lawson, E. T., \& Bentil, G. (2014). Shifting sands: Changes in community perceptions of mining in ghana. Environment, development and sustainability, 16(1), 217-238.

Lawson, G. W. (1985). Plant life in west africa. Accra, Ghana: Universities Press.

Loo, L.-C., Song, G.-Z. M., \& Chao, K.-J. B. S. (2017). Characteristics of topical human-modified forest after 20 years of natural regeneration.

Magurran, A. E. (2013). Measuring biological diversity. John Wiley \& Sons.

Magurran, A. E., \& Henderson, P. A. (2003). Explaining the excess of rare species in natural species abundance distributions. Letters to Nature, 422, 714-716.

McQuilken, J. T. (2016). 'Ethical gold' in sub-saharan africa: A viable empowerment strategy? International Development Planning Review, 38(2), 179-199.

Mensah, A. K. (2015). Role of revegetation in restoring fertility of degraded mined soils in ghana: A review. International Journal of Biodiversity and Conservation, 7(2), 57-80.

MinCom. (2015). Justification for ghana's participation in the iied asm dialogue project. Proceedings from IIeD Conference. London, UK: IIED.

Morgan, R. P. C. (2005). Soil erosion and Conservation (3rd ed.). London, UK: Blackwell Publishing Company Ltd.

Naidu, M. T., \& Kumar, A. O. (2016). Tree diversity, stand structure, and composition of tropical forests in eastern ghats of andhra pradesh, india. Journal of Asia-Pacific Biodiversity, 9(3), 328-334.

Naidu, M. T., Premavani, D., Suthari, S., \& Venkaiah, M. (2018). Assessment of tree diversity in tropical deciduous forests of northcentral eastern ghats, india. Geology, Ecology, and Landscapes, 2(3), 216-227.

Oduro, K. A., Duah-Gyamfi, A., Acquah, S. B., \& Agyeman, V. K. (2012). Ghana forest and wildlife handbook: A compendium of information about forests and wildlife resources, forestry-related issues and wood processing in ghana: CSIR-Forestry Research Institute of Ghana.

Pappoe, A. N. M., Armah, F. A., Quaye, E. C., Kwakye, P. K., \& Buxton, G. N. T. (2010). Composition and stand structure of a tropical moist semi-deciduous forest in ghana. International Research Journal of Plant Science, 1(4), 95-106.

Phillips, O. L., Hall, P., Gentry, A. H., Sawyer, S. A., \& Vasquez, R. (1994). Dynamics of species richness of tropical rain forests. Proceedings of National Academy of Sciences. Washington, DC, USA: National Academy of Sciences.

Pielou, E. C. (1969). An introduction to mathematical ecology. New York, USA: Wiley Publishing.

Sahoo, T., Panda, P. C., \& Acharya, L. (2017). Structure, composition and diversity of tree species in tropical moist deciduous forests of eastern india: A case study of nayagarh forest division, odisha. Journal of Forestry Research, 28(6), 1219-1230.

Shannon, C. E., \& Weiner, W. (1949). The Mathematical Theory of Communities. Urbana, USA: University of Illinois Press.

Simpson, E. H. (1949). Measurement of Diversity, Nature, 163-618. 
Sundarapandian, S., \& Karoor, P. J. (2013). Edge effects on plant diversity in tropical forest ecosystems at periyar wildlife sanctuary in the western ghats of india. Journal of Forestry Research, 24(3), 403-418.

Swamy, S. L., Dutt, C. B. S., Murthy, M. S. R., Mishra, A., \& Bargali, S. S. (2010). Floristics and dry matter dynamics of tropical wet evergreen forests of western ghats, India. Curr Sci, 99(3), 353-364.

Tarakeswara, N. M., Premavani, D., Suthari, S., \& Venkaiah, M. (2018). Assessment of tree diversity in tropical deciduous forests of northcentral eastern ghats, india. Geology, Ecology, and Landscapes, 2(3), 216-227.

Tchouto, M. G. P. (2004). Plant diversity in a central african rain forest, implications for biodiversity conservation in cameroon. Retrieved from https://www.researchgate.net/.../40122511_Plant_diversity in_a_Central_African_rain_f.

Tom-Dery, D., Dagben, Z. J., \& Cobbina, S. J. (2012). Effects of Illegal Small-Scale Mining Operations on Vegetation Cover in Arid Northern Ghana. Research Journal of Environmental and Earth Sciences, 4(6), 674-679.

\section{Copyrights}

Copyright for this article is retained by the author(s), with first publication rights granted to the journal.

This is an open-access article distributed under the terms and conditions of the Creative Commons Attribution license (http://creativecommons.org/licenses/by/4.0/). 